\title{
North American Deer Mouse, Peromyscus maniculatus, Consuming a Parasitizing Botfly Larva, Diptera: Cuterebridae
}

\author{
FranCEs E. C. SteWART
}

Department of Integrative Biology, University of Guelph, 50 Stone Road East, Guelph, Ontario N1G 2W1 Canada; email: fstewart@uoguelph.ca

Stewart, Frances E. C. 2011. North American Deer Mouse, Peromyscus maniculatus, consuming a parasitizing botfly larva, Diptera: Cuterebridae. Canadian Field-Naturalist 125(1): 65-66.

During a laboratory study in Algonquin Provincial Park, Ontario, Canada, I videotaped a female North American Deer Mouse, Peromyscus maniculatus gracilis, consuming a botfly larva, Family Cuterebridae, that had just emerged from her chest. Although botfly parasitism has been widely studied in several species of small mammals, there are no prior reports of the host consuming the emerged botfly parasite.

Key Words: North American Deer Mouse, Peromyscus maniculatus, botfly, Cuterebridae, parasitism, nest defense.

The diet of the North American Deer Mouse (here after deer mouse), Peromyscus maniculatus gracilis (Wagner 1845), can vary depending on its location, season, and in some cases interspecific competition with the White-footed Mouse, P. leucopus (Wolff et al. 1985; Falls et al. 2007). However, the deer mouse is primarily known to be an opportunist, obtaining nutrition from an array of sources such as arthropods, fruit, nuts, green vegetation, and carrion (Hamilton 1941; Schieck and Millar 1985; Wolff et al. 1985). Despite this wide variety, I found no reference to deer mice consuming botfly larvae and, more specifically, their own parasites.

Botflies, are found throughout the geographical distribution of the deer mouse. They are known to parasitize many species of small mammals, however, one of their typical hosts is Peromyscus and parasitism may be as high as $70 \%$ in a given year (Dunway et al. 1967; Slansky 2007). While botfly parasitism is common among small mammal populations in Algonquin Provincial Park (personal observation), there is no documented case of botfly consumption by their mammalian host. In this paper, I describe one instance of a female deer mouse eating a botfly larva three hours after the larva began to emerge. To my knowledge, this is the first recorded observation of a small mammal consuming a botfly larva, and the first recorded observation of a small mammal consuming its own endoparasite.

\section{Observations}

In August 2010, wild P. maniculatus were housed in a laboratory setting at the Algonquin Wildlife Research Station in Algonquin Provincial Park, central Ontario, Canada $\left(45^{\circ} 37^{\prime} \mathrm{N}, 78^{\circ} 21^{\prime} \mathrm{W}\right)$ as part of a pilot study quantifying maternal care in this species. Throughout this study, pregnant female deer mice were trapped using Sherman live-traps and housed in a laboratory holding facility prior to parturition. Females gave birth within several days of capture and the mother and pups were videotaped for seven days post partum.

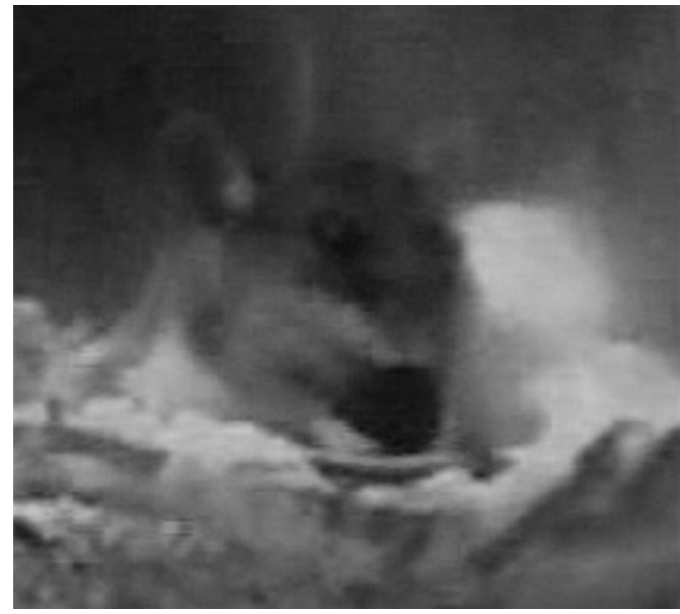

FIGURE 1. A still photo obtained from video footage of a female deer mouse consuming a recently emerged parasitizing botfly larva directly above her nest containing four pups, Algonquin Provincial Park, August 9,2010 . Although of inadequate resolution, the relative size of botfly larva to deer mouse as well as the stance the female assumes while eating the botfly larva are adequately portrayed in this figure.

This particular observation was made post-parturition on a study female that gave birth on 3 August 2010 at $5 \mathrm{pm}$. Only one individual in the study was infected with a botfly parasite, thus comparison among individuals was not possible. The parasitized female had a botfly developing in her upper left chest prior to capture. On the morning of the sixth day of postpartum observations (9 August) the botfly larva had partially emerged. By evening, the botfly larva was no longer visible in the cage; the only evidence of its existence was the wound left on the mother's chest from where it had emerged. Upon review of the day's video footage it was evident that the female had consumed the botfly larva. The video record showed the botfly 
larva beginning to emerge on 9 August at 9:51 am. The botfly larva fully emerged from the female at 13:04 hr and fell to the cage floor directly beside her nest, which contained four pups (six days old). The larva measured approximately $1.5 \mathrm{~cm}$ in length, $1 \mathrm{~cm}$ in diameter and was in its third instar. The female did not react to the larva for approximately 22 minutes, at which time she picked it up. The female instantly positioned herself above her nest and held the botfly larva with both paws. She began to eat the botfly at 13:26 hr and finished at 13:32 hr, continuously turning the larva clockwise with her right paw.

\section{Discussion}

This appears to be the first documented report of a deer mouse eating a parasitic botfly larva. Although, owing to its consumption, I am unable to identify the larva to species, it is likely that the larva belonged to either Cuterebra fontinella or C. americana due to species distribution and host-species preference (Catts 1982). In Algonquin, botfly parasitism fluctuates seasonally with most infestations occurring between late July and October (Slansky and Kenyon 2002) and Peromyscus individuals can have between zero and three botflies at any point (personal observation). Several studies have investigated the behavioural effects of botfly parasitism and have determined that botflies generally have little effect on Peromyscus compared to atypical hosts, such as non-native rodents, lagomorphs, and Carnivora, which experience physiological and behavioural changes resulting in decreased activity, food intake, and reproductive success (Slansky 2007). Nonetheless, individuals can be adversely affected by botfly parasitism, and a smaller dispersal distance from the natal nest was noted in the offspring of parasitized individuals (Wolf and Batzli 2001; Jaffe et al. 2005). I offer this account of a female deer mouse eating a parasitizing botfly as the first account of a mechanism by which deer mice may mitigate the effects of botfly parasitism.

Researchers studying foraging, diet, and nutrition of deer mice rely primarily on stomach content analysis techniques to determine dietary composition (Millar et al. 1990). Although this method is relatively effective at determining nutritional composition and digestibility, it does not provide insight into the behavioural mechanisms by which individuals obtain their food. For example, through gut analysis, it has been known for almost 70 years that deer mice consume arthropods (Hamilton 1941; Wolff et al. 1985), some of which may be botflies. However, the incentive behind this mechanism of prey acquisition remains to be investigated.

Due to this observation occurring in a laboratory setting, I am unable to determine whether this behaviour occurs in free-ranging individuals. However, I foresee two reasons that are not mutually exclusive for a lactating female deer mouse to consume a botfly larva in the vicinity of her nest; (1) she consumes the botfly as a source of nutrition, or (2) she consumes the botfly larva to prevent pupation in the direct vicinity of her pups. Unlike this laboratory situation, wild mice do not have access to food ad libitum and are likely to consume high nutrient foods when available. However, botfly infestations have also been observed in nestbound infant rodents, who were deleteriously affected due to their small size and high-energy demand for growth (Slansky and Kenyon 2002). Therefore, either of the above-mentioned mechanisms may account for this female consuming the botfly in the direct vicinity of her nest and additional research is required to determine the incentives and to assess the generality of this strategy for mitigating parasitism in small mammals.

\section{Acknowledgements}

I am grateful to Rory Eckenswiller and Adam Wilson, as well as Amy Newman, Ryan Taylor, and two anonymous reviewers for providing insightful comments on earlier versions of the manuscript. This observation was made while pursuing research that was supported by funding to Andrew McAdam from the Natural Sciences and Engineering Council of Canada and the Ontario Ministry of Research and Innovation.

\section{Literature Cited}

Catts, E. P. 1982. Biology of New World botflies: Cuterebridae. Annual Review of Entomology 27: 313-338.

Falls, J. B., E. A. Falls, and J. M. Fryxell. 2007. Fluctuation of deer mice in Ontario in relation to seed crops. Ecological Monographs 77: 19-32.

Hamilton, W. J., Jr. 1941. The food of small forest mammals in eastern United States. Journal of Mammalogy 22: 250263.

Jaffe, G., D. A. Zegers, M. A. Steele, and J. F. Merritt. 2005. Long term patterns of botfly parasitism in Peromyscus maniculatus, P. leucopus, and Tamias striatus. Journal of Mammalogy 86: 39-45.

Millar, J. S., X. Xia, and M. B. Norrie. 1990. Relationships among reproductive status, nutritional status, and food characteristics in a natural population of Peromyscus maniculatus. Canadian Journal of Zoology 69: 555-559.

Schieck, J. O., and J. S. Millar. 1985. Alimentary track measurements as indicators of diets in small mammals. Mammalia 49: 93-104.

Slansky, F., and L. R. Kenyon. 2002. Botfly (Diptera: Cuterebridae) infestation of nest-bound infant eastern gray squirrels. Florida Entomologist 85: 269-371.

Slansky, F. 2007. Insect/mammal associations: Effects of Cuterebrid botfly parasites on their hosts. Annual Review of Entomology 52: 17-36.

Wagner, A. 1845. Archiv für Naturgeschichte 11: 148.

Wolf, M., and G. O. Batzli. 2001. Increased prevalence of botflies (Cuterebra fontinella) on white-footed mice (Peromyscus leucopus) near forest edges. Canadian Journal of Zoology 79: 106-109.

Wolff, J. O., R. D. Dueser, and K. S. Barry. 1985. Food habits of sympatric Peromyscus leucopus and P. maniculatus. Journal of Mammalogy 66: 794-798.

Received 12 October 2010

Accepted 2 December 2010 